\title{
Black Britain and the Politics of Race in the 20th Century
}

\author{
Kennetta Hammond Perry* \\ East Carolina University
}

\begin{abstract}
This essay examines a growing literature on postcolonial Black Britain that seeks to suture the ties between prewar and postwar histories of Black political activity in Britain. By examining how people of African descent articulated the political conditions of being Black in metropolitan Britain during the 20th century, recent studies have shown how non-state actors shaped ideas about the relationship between race and citizenship. In unearthing the myriad of ways that people of African descent navigated the politics of being both Black and British, this body of work has begun to offer critical perspectives on postcolonial Black Britain's place within the political history of the African Diaspora. Moreover, this essay argues that new work on Black Britain and the politics of race yields fruitful ground for dismantling some of the artificial historiographical partitions that have oftentimes separated metropolitan race politics in the postwar era from the broader history of empire, decolonization, and transnational anti-racist movements organized around the pursuit of Black freedom.
\end{abstract}

For decades, the arrival of passengers aboard the Windrush at Tilbury Docks in June of 1948 served as the primary point of entry for understanding the formation of postcolonial Black Britain. Visual frames of newsreel footage documenting hundreds of West Indian men disembarking from the Windrush and sharing the optimism expressed in Lord Kitchener's famous calypso "London Is The Place For Me" provided powerful optics used to caption histories of how New Commonwealth migration facilitated what has been described as the "irresistible rise of multiracial Britain" in the decades following the Second World War. ${ }^{1}$ More recently, however, scholars have been much more critical of the occlusions and silences embedded in histories, which take the journey of the Windrush passengers as "the originary moment" for understanding the development of postcolonial Black Britain and accompanying questions regarding 'race relations', citizenship, belonging, and notions of Britishness. ${ }^{2}$ Historians, in particular, have lead the way in moving beyond the customary identifications attached to the Windrush in an effort to reflect the complexities and contingencies that informed racial (trans) formations in Britain during the 20th century. Whereas popular narratives about the Windrush generation largely centered upon the experiences of single West Indian men, Wendy Webster and Mary Chamberlain have documented the voices of Afro-Caribbean women and children and analyzed how gender and familial ties shaped the terms by which migrants made a place for themselves in British society. ${ }^{3}$ Because the mythology surrounding the Windrush foregrounds movement between the Caribbean and Britain as a focal point of understanding the growth of multiracial communities following World War II, the work of David Killingray, Laura Tabili, and Rozina Visram has proven vital in detailing the wider 20th century history of global and inter-imperial migration from continental Europe, Asia, and Africa to the British Isles and its impact on ideas about race and national identity in Britain before, during, and after World War II. ${ }^{4}$ Following classic surveys including Peter Fryer's groundbreaking Staying Power, their work highlights how non-White settlers and transient groups including seamen, students, soldiers, ayahs, and colonial elites encountered discrimination, harassment, xenophobia, and episodes of racial violence in major urban centers and port towns. ${ }^{5}$ 
Beyond offering a limited view of the range of perspectives and experiences that shaped the contours of what would become postcolonial Black Britain, what has been central to the various permutations of the 'Windrush-as-origins' discourse is the idea that postwar Black migrations, and more specifically, White Britons' responses to these movements, were the requisite starting point for explaining the emergence of race as a domestic political issue in the decades following World War II. The passage of policies including the Commonwealth Immigrants Act of 1962 and a series of Race Relations Acts that linked anti-immigration and anti-discrimination measures became the primary focal points for debating the extent to which the state institutionalized racially exclusionary boundaries of citizenship and belonging, which reflected a broader White public's anxieties about demographic shifts prompted by New Commonwealth migration. ${ }^{6}$ As a result, we initially learned a great deal about the motives and intentions of policymakers and their interlocutors in politicizing race by cultivating narratives that conflated "immigrants" with a perceived "color problem." However, we learned little about how migrants' everyday experiences of racism, discrimination, inadequate police protection, and violence worked to animate and redefine Black political life in Britain.

This essay examines a growing literature on postcolonial Black Britain that seeks to suture the ties between prewar and postwar histories of Black political activity in Britain by connecting the threads between the local, the imperial, and the global. While there has been some debate about the various ethnicities, colonial nationalities, and cultural identifications, which have populated the histories of Black Britain over time, much of the recent scholarship tends to reflect contemporary cultural and political markers of Black Britishness in centering the narratives of people of African descent from former British colonies in Africa and to a greater extent, the Caribbean. ${ }^{7}$ By examining how people of African descent articulated the political conditions of being Black in metropolitan Britain, recent studies have shown how non-state actors shaped ideas about the relationship between race and citizenship. Moreover, in unearthing the myriad of ways that people of African descent navigated the politics of being both Black and British, this body of work has, by necessity, begun to offer critical perspectives on postcolonial Black Britain's place within the political history of the African Diaspora and the history of what Robin Kelley and Tiffany Patterson have described as Black globality. According to Kelley and Patterson, Black globality offers a language to capture the intersections between the formations of Black political life and internationalist currents that transcend and crisscross the boundaries of nation-states including but not limited to anti-racism, anti-colonialism, feminism, socialism, and antifascism. ${ }^{8}$ In highlighting these connections, I argue that recent scholarship has offered fruitful ground for not only rethinking much of the 'Windrush-as-origins' discourse but also dismantling some of the artificial historiographical partitions that have oftentimes separated metropolitan race politics in the postwar era from the broader history of empire, decolonization, and transnational dialogs and anti-racist movements organized around the pursuit of Black freedom.

Historians of the Victorian era have drawn our attention to the entanglements between the domestic and the imperial by imaginatively reconstructing the mutually constitutive racialized worlds of the metropole and the colony. ${ }^{9}$ Yet we are only beginning to ask questions about how the racial ideologies that underpinned the political, social, and cultural processes that informed decolonization as a lived experience shaped how metropolitan Britons grappled with the declining significance of British imperial power in the world during the latter half of the 20th century. Recent monographs by Bill Schwarz, who tackles how memories of empire informed ideas about whiteness in the post-imperial metropolis, and Jordanna Bailkin, who historicizes the relationship between the social realities of decolonization and the emergence of the postwar welfare state, offer fresh insights that will certainly drive new questions about the residual effects of Britain's imperial past on postwar issues concerning race, nationhood, and national belonging. ${ }^{10}$ But, undoubtedly, there remain more angles to consider. By 
centering Black Britons as both political and politicized subjects while underscoring some of the continuities in Black life in Britain throughout the 20th century, recent scholarship has offered new ways of thinking about the political salience of race in metropolitan Britain. Likewise, in raising new questions about the dynamics of race and citizenship as seen from the vantage point of Black Britons, it has also invited new conversations about the roles that people of African descent have played in decolonizing the very idea of what it means to be British.

\section{Confronting the 'Race Relations' Paradigm}

In 1987 with the publication of his groundbreaking monograph There Ain't No Black in the Union Jack, Paul Gilroy helped to define the terms of an ongoing debate about the relationship between race and ideas about nationhood and national belonging in Britain. At the heart of Gilroy's analysis of the cultural politics of race and nation was a critique of the ways in which blackness as a racialized political category had been systematically rendered incompatible with notions of Britishness. According to Gilroy, "strategic silences" about the history of the Black presence in Britain coupled with the persistent fiction of national homogeneity helped to crystallize popular conceptions of the nation as an 'Island Race' whose boundaries of inclusion and exclusion had only recently been upset by a relatively new population of non-White migrants intent on staying and forging a sense of belonging in British society. ${ }^{11}$ What is crucial to note about the context in which Gilroy develops a discussion about race, nation, culture, and the histories of Black Britain is that his ideas took shape against the backdrop of a historiographical turn marked by a critical interrogation of the state's role in institutionalizing anti-Black racism. Whereas the sociological analysis of race relations pioneered by Kenneth Little and institutionalized in the early work of the Institute of Race Relations had largely examined de facto 'color bars' and interpersonal racial prejudices held by White Britons, beginning in the late 1970s and early 1980s, there was a decisive shift in the study of race and anti-Black racism in Britain. $^{12}$

In a decade marked by uprisings in Brixton, national media focus on the racially disparate impact of policing practices, and a series of conservative policies that produced an acute shortage of economic resources including jobs, social services, housing, and education among working class Black constituencies, a cadre of scholars aimed to highlight the historical processes that produced official policies of racialized disenfranchisement. Thus, the state became a prime actor in understanding the operation of racism and, consequently, the politics of race in Britain. In an unpublished dissertation, Lydia Lindsey was one of the first historians to utilize newly released Government records to demonstrate how British officials - independent of popular opinion actively participated in constructing and appropriating racist stereotypes about Black workers, which were then used as a premise to rationalize discriminatory policies including the Commonwealth Immigrants Act of 1962. ${ }^{13}$ Building upon work produced during the 1980s and early 1990s by sociologists including Shirley Joshi, Clive Harris, Bob Carter, Zig LaytonHenry, and Robert Miles who had begun to examine the state's role in institutionalizing racism, Lindsey's work challenged the central premise of earlier historical scholarship that had suggested that British officials were pressured by popular opinion and political expediency to institute policies designed to deliberately undermine the citizenship rights of what was at the time a largely Afro-Caribbean stream of Commonwealth migrants.

For over a decade, what Randall Hansen dubbed the "racialization thesis" dominated historical scholarship on postwar race politics in Britain. ${ }^{15}$ Whereas the proponents of the socalled racialization school positioned the state as a central conduit of racist ideologies that equated Britishness with whiteness and used this logic to justify racially exclusionary migration controls, Hansen insisted that a constellation of factors shaped government policy on nationality 
and immigration including popular hostility toward Black migrants and the tenuous relations of a decolonizing Commonwealth with competing national interests. ${ }^{16}$ Although Hansen's conclusions diverged from the emerging scholarly consensus, his work adopted the prevailing state-centered approach that historians including Kathleen Paul and Ian Spencer had relied upon to persuasively demonstrate the active and sustained interest of successive British governments in limiting Black migration and the growth of Black communities in Britain throughout the 1950s. In addition to establishing Government officials' interests in controlling a largely Afro-Caribbean Commonwealth migration stream well before the issue became a subject of public debate in the aftermath of highly publicized incidents of racial violence in Nottingham and London during the summer of 1958, Paul and Spencer focused on the extent to which racism and racialized visions of the boundaries of Britishness guided officials' reactions to what they deemed to be alarming numbers of Black migrants in the postwar period. Moreover, they demonstrated that policymakers' inability to imagine the legitimacy of Black migrants' claims to a British nationality and, conversely, British citizenship determined their motives and prescriptions for border controls. 17

Scholarly debate over the extent to which the state played a role in either producing or reinforcing racialized conceptions of citizenship, nationality and rights of belonging in postwar Britain shed new light on some of the historical processes that rendered blackness incongruous with notions of Britishness. However, these conversations - which in many ways reinforced the 'Windrush-as-origins' discourse - tended to narrowly confine the politicization of race to an arena composed of a policymaking elite reacting to an unwelcomed postwar Black presence. Recent scholarship has demonstrated that there existed a much larger terrain of political activity engaging issues of race, citizenship, and the status of Black people in Britain that extended well beyond the corridors of Whitehall. Taking up Paul Gilroy's earlier calls to move beyond ahistorical race relations approaches that represented Black people as "objects rather than subjects," and to trace the transnational circuits of mobility, exchange, appropriation, and collaboration that have informed Black Britain's place in a larger Black Atlantic world, in the last decade, historians have begun to uncover the myriad of ways in which Black populations in Britain forged a politics of race that simultaneously challenged their disenfranchisement and articulated the legitimacy of their claims of being both Black and British. ${ }^{18}$ In doing so, not only are they transforming conventional narratives about race and nation in Britain, but they are also offering new ways of thinking about how the Windrush moment and the generation of postwar Black migrations that accompanied it functioned as a transition point linking the political histories of a decolonizing imperial metropolis and a Black diaspora constituted by a diversity of movements for citizenship, national selfdetermination, independence, equality, and the freedom to belong.

\section{Anti-colonial Black Britain}

In his study of West Indian intellectuals in 20th century Britain, Bill Schwarz reminds historians of the importance of understanding the intellectual baggage that Caribbean migrants brought to Britain, which informed how they engaged life in the metropole. In addition to recognizing that migrants arrived with memories of life in the colonies that would come to bear upon their experience of forging Black British identifications in the metropole, Schwarz insists that it is imperative to consider how the extant realities of decolonization, intensifying Black freedom movements in the United States, and the internationalization of anti-apartheid sentiment shaped the consciousness of a postwar generation of West Indian migrants. While Schwarz firmly situates the postwar transoceanic movements of Afro-Caribbean migrants, their campaigns for citizenship and their efforts to challenge racism in Britain as part and parcel of a diasporic political sphere that was at once local and global in its orientation, the bulk of historical 
work that has employed a transnational lens to bring into focus the cross-fertilization of anti-racist, anti-colonialist, and leftist thought shaping Black political life in Britain during the 20th century is largely centered on the interwar period. ${ }^{19}$

During the 1930s and 1940s, urban spaces like London served as a fulcrum of diasporic encounter and collaboration between Black organizers and intellectuals largely from British colonies in the Caribbean and West Africa. Classic works including Immanuel Geiss's The Pan-African Movement and Cedric Robinson's Black Marxism as well as important surveys by P. Olisanwuche Esedebe and Ronald Walters detail how efforts to mobilize a global fight against the comfortable bedfellows of colonialism, racism, fascism, ideologies of White supremacy, and capitalist exploitation fueled the development of a vibrant transnational Black political culture that produced international organizations and drove the expansion of a diasporic print media that drew audiences in Britain, the Caribbean, the United States, and Africa. ${ }^{20}$ Duse Mohammed Ali's African Times and Orient Review and The Keys, an organ of the League of Coloured Peoples, challenged the premise of benevolent imperial rule in Africa and the Caribbean and highlighted racial tensions in Britain during the early 20th century as part of a broader strategy of linking the interests of Black people in Britain to a global Black world.

In addition, work on the interwar period has profiled the activities of key Black radical thinkers including C. L. R. James and the histories of important organizations based in Britain including the International African Service Bureau, the Negro Welfare Association, and the Pan-African Congress movement championed by W. E. B. DuBois, which held one of its most important meetings in Manchester in 1945 bringing together continental Africans, labor leaders, and activists from across the African Diaspora. Coupled with biographical work on major figures involved in these movements including Henry Sylvester Williams, George Padmore, Harold Moody, Una Marson, and Amy Ashwood Garvey who established the Florence Mills Social Club, which became a meeting ground for London's emerging Black intelligentsia during the 1930s, work on Black political activity during this period has established Britain's strategic role as both a seat of imperial power and, consequently, an incubator of Pan-Africanist thought. ${ }^{21}$ In doing so, this body of scholarship has become foundational in understanding how metropolitan Britain, and London in particular, was akin to spaces like Harlem and Paris as it provided a critical hub of exchange, coalition building, and cross-national identification that in turn facilitated the political relations of the African Diaspora in the first half of the 20th century. ${ }^{22}$

While biographies of important, but to some extent, largely exceptional figures who left a significant archival footprint because of their literary output, published political writings and/ or their representation in print media continue to animate work on Black political activity in interwar Britain, recent monographs produced by Susan Pennybacker and Minkah Makalani have employed biography and intellectual history to explore how Black activists in Britain created a world of transnational dialogs and solidarities, which facilitated leftist and anti-racist activism. With particular attention to the 1930s, Pennybacker invokes the international campaign to seek justice on behalf of nine young African-American youths accused of raping two White women in the infamous trial of the "Scottsboro boys" as a point of departure to examine the converging political worlds of communists, civil rights advocates, socialists, liberal reformers, nationalists, Pan-Africanists, and those in opposition to fascist aggression who cultivated a type of globally oriented race politics. ${ }^{23}$ Traversing some of the same archival terrain that Pennybacker employs to document the shifting coalitions that both frustrated and sustained the anti-racist work of the Comintern throughout the 1930s, Minkah Makalani's In the Cause of Freedom offers a different context for understanding the shape and scope of Black political activity in interwar Britain. Beginning with the work of Cyril Briggs and the African Blood Brotherhood, Makalani shows that Black radicals in Harlem and London built trans-Atlantic 
political alliances with Asian radicals including Manabendra Nath Roy, who then helped shape debates within the Comintern about the relationship between race and empire. Not only does his work offer a means of understanding how Black radicals based in London including George Padmore came to embrace socialism as a vehicle for promoting Pan-Africanism's challenge to racism and colonialism, but much like Hakim Adi's new biography on Padmore, it also demonstrates how Black intellectuals and activists worked to expose the limits of a solely class-based approach to building a mass international proletarian revolution. ${ }^{24}$

Pennybacker and Makalani's monographs, as well as forthcoming work by Eric D. Duke examining the place of race within diasporic debates over Caribbean federation, and Marc Matera, who traces how African and Caribbean intellectuals forged a type of global Black consciousness within the context of the interwar British imperial metropolis, joins a growing body of scholarship produced primarily in the U.S. academy in the last two decades, focused on Black internationalism and transnational race politics. ${ }^{25}$ Much of this work tends to explore how U.S.-based Black activists tethered opposition to and critiques of Jim Crow to a broader diasporic struggle for Black freedoms compromised in the face of global systems of colonialism, disenfranchisement, and White supremacist power and oppression. Scholars including Penny Von Eschen, Carol Anderson, Glenda Gilmore, Gerald Horne, Robin D. G. Kelley, Kevin Gaines, and Brenda Gayle Plummer have offered important studies profiling African-American activists, organizations, and institutions, including the Black press, whose political imaginaries stretched beyond the confines of national boundaries. ${ }^{26}$ Through their attention to the connections between the local and the global, we are better able to understand how anti-communism and the Cold War exacerbated tensions between organizations like the NAACP and the Black left and how U.S. diplomatic agendas offered crucial openings to leverage the power of the international community for the cause of Black freedom. Moreover, in chronicling the extent to which African-Americans engaged internationally and diasporically in shaping social and political movements vested in a range of disparate, yet oftentimes intersecting ideological commitments including communism, socialism, feminism, anti-colonialism, Black nationalism, and Pan-Africanism, this body of work has necessarily helped to broaden the field of vision for understanding the plurality and elasticity of forms of Black internationalism that emerged throughout the 20th century.

\section{Black Power in a British Frame}

It is precisely the issue of how Black political agents from various formal and informal positions forged pliable discourses of Black internationalism that were mobile, translatable, and adaptable that has animated a growing body of scholarship on transnational race politics in postwar Britain. In particular, a burst of scholarship in a burgeoning subfield, which historian Peniel Joseph has described as "Black Power Studies," has offered new ways of thinking about the global reach of Black freedom struggles in the United States and beyond. ${ }^{27}$ In doing so, Joseph and others including Kathleen Cleaver, Quito Swan and, more recently, Nico Slate have begun to track the global valences of Black Power and its disparate ideological, rhetorical, and organizational contours. $^{28}$ Mapping the historical formation and impact of articulations of Black Power in postwar Britain has been at the core of some of the most exciting scholarships aiming to understand how a first and second generation migrant population of Black British citizens appropriated blackness as a political category and engendered a local politics of race that linked their intentions to make a place for themselves within British society as rights-bearing citizens with a wider struggle against the vestiges of colonialism and White supremacy. In her work on the emergence of the Black Panther Party in London and the history of Black Power in Britain, Anne-Marie Angelo finds that while Black Power proponents in Britain during the late 1960 s and 1970s were drawn to the esthetics and iconography of the U.S. Black Panther Party, 
they developed their own iterations of Black Power that were specifically formatted to the conditions of Black life in Britain. Angelo contends that while 'Black America' functioned as a "rhetorical and stylistic benchmark for oppression and resistance," Black Power politics in Britain was driven by the immediacies of a racially charged local political scene shaped by discriminatory immigration laws, tense relations with police, imperial decline, and the absence of a coherent metropolitan history of de jure racial practices akin to Jim Crow. ${ }^{29}$

The variegated nature of Black Power in Britain is the central focus of recent work by Robin Bunce and Paul Field appearing in one of the leading British history journals comparing and contrasting the interpretations of Black Power as imagined by veteran Black radical theorist C. L. R. James and Nigerian-born writer Obi Egbuna, who founded one of the earliest organizations explicitly advocating Black Power in Britain, the United Coloured People's Association. Citing the celebrated 1967 Dialectics of Liberation conference, which featured Stokely Carmichael as a key moment in the "formation of an indigenous Black power movement," Bunce and Field trace how Egbuna and James arrived at different conclusions about the genealogy of the movement, the place of White sympathizers in the movement as well as the organizing strategies that should be applied to build an effective movement for Black Power. Recognizing C. L. R. James as a figure whose activism spanned the interwar and postwar years, they note that James traced the evolution of Black Power politics in Britain through a longer history of Black internationalist praxis associated with the likes of Black nationalists including Marcus Garvey, and Pan-Africanists including W. E. B. Dubois and George Padmore, whom he had partnered with a generation earlier in establishing London as a hub of diasporic politics during the 1930s. ${ }^{30}$ For James, Black Power was not simply an American import that would attract notable figures including Darcus Howe, one of the defendants and legal strategists in the infamous 1971 Mangrove Nine trial. ${ }^{31}$ Rather, it was beholden to a history of transnational organizing and claim making by Black constituencies based in Britain.

Recent studies by Rosie Wild and Joshua Guild offer important glimpses into the broader imperial, anti-colonial, and postcolonial backdrops informing the ways in which Black Power became politically viable in Britain during the late 1960s and 1970s primarily among AfroCaribbean and African migrants seeking to articulate what it meant to be both Black and British. Both pay attention to the ways in which the configurations of race and blackness in Britain worked in particular ways to engender versions of Black Power that sought to accommodate a range of ethnic and cross-racial coalitions at particular moments around specific political issues including (im)migration in ways that differed from previous Black internationalist organizing in Britain and in the United States. According to Wild, British Black Power was rooted in a "tradition of metropolitan anti-colonialism" that ultimately worked to "bridge the racial divide between Asian, West Indian and African immigrants and their differing experiences of colonialism." ${ }^{32}$ Whereas Wild offers one of the most comprehensive studies to date on the various individuals and collectives espousing Black Power in Britain and their political platforms, which included support for African liberation, Irish Republicanism, and anti-apartheid resistance as well as domestically oriented agendas concerning education and policing, Joshua Guild places the rise of Black Power in Britain in comparative perspective. From his work on postwar Brooklyn and London, we learn a great deal about the importance of understanding Black Power politics within the context of Black migration and the transformation of urban communities - dynamics, which he notes have been critical in shaping the modern African Diaspora. ${ }^{33}$

At this point, racial politics in the US looms large in histories seeking to imagine Black Britain's place in a Black Atlantic postwar political culture. Writing about Malcolm X's visit to Oxford in 1964, Stephen Tuck insists that during the 1960s, there was a perception of a "special relationship" between the United States and Britain that encompassed matters of race. Tuck observes that the 
British-American relationship on race highlights the many different purposes to which the American story could be put, the compatibility of comparative and historie croisée approaches, the early salience of what would come to be known as Black Power ideology in Britain and the United States, and the persistent influence of Atlantic connections even in a global age. ${ }^{34}$

Tuck joins a chorus of scholars interested in developing a more nuanced accounting of the circulation of people, political vernaculars, ideologies, and cultural paraphernalia between the United States and Britain during the 20th century to understand how the politics of race in postwar Britain fits within a larger historical moment shaped by the exigencies of global struggles for Black freedom in an age of decolonization, Cold War, anti-apartheid activism, and international debates about the elimination of racial discrimination and the protection of human rights. ${ }^{35}$ What is most promising about this body of work on the study of the transnational dimensions of race politics in postwar Britain is that it pushes historians of Britain to move beyond the colonial-metropolitan axis in exploring how people of African descent, and for that matter, a number of racialized subject peoples navigated the politics of empire in relation to a global and diasporic Black world that was at once internationally oriented and constituted by nationally specific conditions of race. Moreover, by giving greater visibility to the ways in which Britain's role as an arbiter of imperial power allowed it to attract and facilitate Black internationalist movements and collaborations throughout the 20th century, historians have new points of departure to expand our understanding of how people of African descent and their varied political commitments continue to shape British history, culture, and society.

\section{Return to the Windrush?}

Looking forward, it appears that scholarship on Black political activity in Britain during the 20th century will continue to upend the symbolism conventionally associated with the journey of the Windrush passengers. But one might consider that rather than negating or erasing the significance of these sojourns to Britain, new scholarship will provide alternative ways of reading the Windrush moment and reimaging its legacy. While the Windrush-as-origins discourse has previously positioned anti-Black racisms held by Parliamentarians and institutionalized in immigration and nationality policies as the focal point of a domestically oriented conversation about the politics of race in postwar Britain, work examining the political efficacy of people of African descent reconfigures this view. Rather than imagining how White audiences including British officials reacted to Lord Kitchener's iconic claim "London is the place for me," we can now begin to see this declaration of belonging, and those of the generation of Afro-Caribbean migrants who followed, as part of a longer history of race, empire, and anti-colonial politics. At its core, this was a type of race politics cultivated through the experience of imperial subjecthood that articulated how people of African descent saw themselves as rights-bearing citizens rather than "immigrants" who stood outside of the boundaries of Britishness because of their skin color, ethnicity, colonial nationality, or newcomer status. ${ }^{36}$ It is precisely in the process of shifting our historical lenses to recognize the myriad of ways that Black people in Britain articulated the conditions of their position as citizens, and their oftentimes fraught relationship to the imperial body politic that historians can unearth the transnational currents, which have shaped the formation of postcolonial Black Britain. From there, it becomes clear how Black British identifications took shape against the convergence of a host of factors including the specificity of domestic race relations, competing racialized imperial ideologies that simultaneously championed Commonwealth multiracialism while upholding hierarchies that privileged metropolitan whiteness, and a postwar international arena attuned to the problem of racism and White supremacy as experienced by a global Black world. 
Those who have explored the connections between Black freedom struggles in the United States and race politics in Britain during the 20th century have demonstrated that as people moved across borders, as news traveled, and as communities organized for civil rights, social justice, and equality before the law strategies were borrowed, political ideologies were appropriated, and political lexicons were adapted and reconfigured to suit specific local interests. As historians continue to examine the records of the British state alongside sources produced by and documenting the everyday lives of Black people in Britain to narrate how race informed the politics of citizenship and belonging in British society, there will be a need to continue to widen the archival base to interrogate these connections. The pages of Claudia Jones's West Indian Gazette newspaper and lesser known publications including Flamingo and Magnet News whose limited runs can be found in such places including the Black History collections held at the Institute of Race Relations in London and the Schomburg Center for Research in Black Culture in New York provide useful starting points. These short-lived publications reveal much about the relationship between Black culture and politics and are useful in understanding, and to some extent, literally visualizing some of the key issues including racial violence, inadequate police protection, and discrimination in housing and employment, which informed how Black Britons framed their marginal citizenship status. Likewise, tracing the activities of organizations including the Committee of Afro-Asian Caribbean Organizations, which staged a solidarity March on Washington movement in 1963 to highlight the discriminatory nature of the provisions of the British immigration policy and the short-lived Campaign Against Racial Discrimination whose history underscores the contestations of representing the political interests of Black Britons, offers a way to understand how Black Power became a viable political vernacular for Black people in Britain during the late 1960s and early 1970s ${ }^{37}$ Considering these topics is crucial to the work of understanding the range of stakeholders who participated in raising the political profile of race in postwar Britain. Moreover, it offers a useful pathway to forge more meaningful scholarly conversations between those who study the history of 20th century Britain and its empire and those who explore the racial politics, which continue to re(make) the modern African Diaspora.

\section{Short Biography}

Kennetta Hammond Perry is an Assistant Professor of History in the Department of History at East Carolina University where she is responsible for teaching courses in Atlantic World History and African \& African-American Studies. Dr Perry's research interests include transnational race politics, Europe and the African Diaspora, and the global dimensions of African-American history. She has published in the Journal of British Studies, and currently, she is completing a book manuscript on Afro-Caribbean migration and transnational race politics in postwar Britain.

\footnotetext{
Notes

* Correspondence: East Carolina University, Department of History, East Fifth Street, Greenville, NC 27858-4353, USA. Email: perryk@ecu.edu
}

1 ITN Footage of Empire Windrush, Gaumont British Newsreel, Reuters, 22 June 1948; Phillips and Phillips, Windrush, 6. See also Spencer, "Lord Kitchener Steps Off the Empire Windrush"; Hiro, Black British, White British; Wambu, Empire Windrush; Proctor, ed., Writing Black Britain, 1948-1998.

2 Hesse, 'Diasporicity', 97-99. This argument has also been a key theme of a body of intellectual work by Stuart Hall. See Hall, "Racism and Reaction"; Hall, "A Question of Identity"; Hall, "Preface," 7. See also Mead, "Empire Windrush," 137-149. 
3 Webster, Imagining Home; Chamberlain, Narratives of Exile and Return; Chamberlain, Family Love in the Diaspora. See also Beverley Bryan et al., Heart of the Race.

4 Killingray, ed., Africans in Britain; Killingray “ 'A Good West Indian, A Good African and in Short a Good Britisher,'” 363-381; Tabili, We Ask For British Justice; Tabili, Global Migrants, Local Culture; Visram, Asians in Britain. See also Adi, West Africans in Britain, and Frost, Work and Community Among West African Migrant Workers Since the Nineteenth Century.

${ }^{5}$ Fryer, Staying Power, see also Ramdin, The Making of the Black Working Class in Britain. On racial violence in the early 20 th century Britain, see Panayi, ed., Racial Violence in Britain, 1840-1950, and Jenkins, Black Riot.

${ }^{6}$ Hampshire, Citizenship and Belonging.

7 Modood, "Political Blackness and British Asians," 859-876; Brah, Cartographies of Diaspora, 96-101. See also Hall, "Ethnicity: Identity and Difference," 339-351, and James, "The Making of Black Identities," 230-255. In his 1987 study on the cultural politics of race, Paul Gilroy notes that the notions of blackness in Britain have "moved away from political definitions of Black based on the possibility of Afro-Asian unity and towards more restrictive alternative formulations which have confined the concept of blackness to people of African descent." He connects this shift to political developments following the 1981 riots and the response of the British Government. Gilroy, Ain't No Black in the Union Jack, 39.

8 Kelley and Patterson, "Unfinished Migrations," 11-45.

9 Thorne, Congregational Missions and the Making of Imperial Culture in Nineteenth Century England; Hall, Civilizing Subjects; McClintock, Imperial Leather.

10 Schwarz, The White Man's World; Bailkin, The Afterlife of Empire. See also Rose, "Who Are We Now?: Writing the Postwar 'Nation', 1948-2001," 154-174. Two earlier works that also analyze the imperial dimensions of postwar race politics include Rich, Race and Empire in British Politics, and Walvin, Passage to Britain.

11 Gilroy, Ain't No Black in the Union Jack, 12, 45, 48. Gilroy's work on these issues began as part of his work with the University of Birmingham's Centre for Contemporary Cultural Studies and ultimately became central to his articulation of the 'Black Atlantic'. See also Gilroy, "Steppin Out of Babylon: Race, Class and Autonomy" in Empire Strikes Back, 278, and Gilroy, The Black Atlantic.

12 Little, Negroes in Britain; Waters, "Dark Strangers in Our Midst," 207-238; Sivanandan, "Race and Resistance: The IRR Story," $1-30$.

13 Lindsey, "The Role of Immigration Policy, Race, Class and Gender in Shaping the Status of Jamaican Immigrant Women Workers in Birmingham, England, 1948-1962."

14 Carter et al., "The 1951-1955 Conservative Government and the Racialization of Black Immigration," 335-47; Carter et al., "Immigration Policy and the Racialization of Migrant Labour," 135-57; Miles, "Nationality, Citizenship and Migration to Britain, 1945-1951," 426-442, and Layton-Henry, The Politics of Immigration. Earlier studies focused on how popular opinion drove policymaking on immigration include Foot, Immigration and Race in British Politics; Deakin, "The Politics of the Commonwealth Immigrants Bill," 25-45; Holmes, John Bull's Island.

15 Hansen, Citizenship and Immigration in Postwar Britain, 10-16.

16 Ibid., 12.

17 Paul, Whitewashing Britain, and Spencer, British Immigration Policy Since 1939.

18 Gilroy, Ain't No Black, 11.

19 Schwarz, ed., West Indian Intellectuals in Britain, 13. See also Schwarz, "Claudia Jones and the West Indian Gazette," 264-285, and Schwarz, The White Man's World, where he outlines a forthcoming trilogy on memories of empire that will take up the cultural politics of race and Caribbean migration in postwar Britain.

20 Geiss, The Pan-African Movement; Robinson, Black Marxism; Esedebe, Pan-Africanism; Walters, Pan-Africanism in the African Diaspora.

21 Høgsbjerg, C. L. R. James in Imperial Britain; Sherwood, Origins of Pan-Africanism; Baptiste and Lewis, Caribbean Reasonings; Rush, "Imperial Identity in Colonial Minds," 356-383; Jarrett-Macauley, The Life of Una Marson, 1905-1965; Martin, Amy Ashwood Garvey.

22 Edwards, The Practice of Diaspora.

23 Pennybacker, From Scottsboro to Munich.

24 Makalani, In the Cause of Freedom; Adi, Pan-Africanism and Communism.

25 Duke, Building a Nation; Matera, Black London.

${ }^{26}$ Von Eschen, Race Against Empire; Anderson, Eyes Off the Prize; Plummer, Rising Wind; Plummer, In Search of Powers; Gilmore, Defying Dixie; Horne, Mau Mau in Harlem; Meriwether, Proudly We Can Be Africans.

27 Joseph, "The Black Power Movement," 752.

28 Joseph, Waiting Til' The Midnight Hour; Peniel Joseph, ed., The Black Power Movement; Cleaver, "Back to Africa,” 211-54; Swan, Black Power in Bermuda; Slate, ed., Black Power Beyond Borders; Jeffries, Bloody Lowndes; Murch, Living For The City; Nelson, Body and Soul. 
29 Angelo, "The Black Panthers in London, 1967-1972," 17-35. For more on the cultural capital of 'Black America' in Britain, see Brown, "Black Liverpool, Black America and the Gendering of Diasporic Space," 291-395.

30 Bunce and Field, “Obi E. Egbuna, C. L. R. James and the Birth of Black Power in Britain,” 391-414.

31 Bunce and Field, Darcus Howe.

32 Wild, "Black Was the Colour of Our Fight," 8.

33 Guild, "You Can't Go Home Again: Migration, Citizenship, and Black Community in Postwar New York and London," PhD Dissertation, Yale University, 2007; Guild, Shadows of the Metropolis.

34 Tuck, "Malcolm X's Visit to Oxford University," 79.

35 Abernathy, "Not Just an American Problem," 285-307; Street, "Malcolm X, Smethwick, and the Influence of the African American Freedom Struggle," 932-950; Ward, “A King in Newcastle: Martin Luther King, Jr. and British Race Relations, 1967-1968,” 599-632; Perry, “'Little Rock' in Britain,” 155-177; Ambar, Malcolm X at Oxford Union.

36 Putnam, "Citizenship from the Margins," 161-192.

37 "London Solidarity March," West Indian Gazette, 13 September 1963; Perry, "U.S. Negroes, Your Fight Is Our Fight”; Heinemann, Politics of the Powerless.

\section{Bibliography}

Abernathy, G., 'Not Just an American Problem: Malcolm X in Britain', Atlantic Studies, 7/3 (2010): 285-307.

Adi, H., West Africans in Britain, 1900-1960: Nationalism, Pan-Africanism and Communism (London: Lawrence and Wishart, 1998).

Adi, H., Pan-Africanism and Communism: The Communist International, Africa and the Diaspora, 1919-1939 (Trenton: Africa World Press, 2013).

Ambar, S., Malcolm X at Oxford Union: Racial Politics in a Global Era (New York: Oxford University Press, 2014).

Anderson, C., Eyes Off the Prize: The United Nations and the African American Struggle for Human Rights, 1944-1955 (Cambridge: Cambridge University Press, 2003).

Angelo, A.-M., 'The Black Panthers in London, 1967-1972: A Diasporic Struggle Navigates the Black Atlantic', Radical History Review, 103 (Winter, 2009): 17-35.

Bailkin, J., The Afterlife of Empire (Berkeley: University of California Press, 2013).

Baptiste, F., and Lewis, R., Caribbean Reasonings: George Padmore, Pan-African Revolutionary (Kingston: Ian Randle, 2008).

Brah, A., Cartographies of Diaspora: Contesting Identities (New York: Routledge, 1996).

Brown, J. N., 'Black Liverpool, Black America and the Gendering of Diasporic Space', Cultural Anthropology, 13, 3 (August, 1998): 291-395.

Bryan, B., S. Dadzie, and Scafe, S., Heart of the Race: Black Women's Lives in Britain (London: Virago Press, 1985).

Bunce, R. E. R., and Field, P., 'Obi E. Egbuna, C. L. R. James and the Birth of Black Power in Britain: Black Radicalism in Britain 1967-1972', Twentieth Century British History, 22/3 (September, 2011): 391-414.

Bunce, R. E. R., and Field, P., Darcus Howe: A Life. London: Bloomsbury, 2014.

Carter, B. C. H., and Joshi, S., 'The 1951-1955 Conservative Government and the Racialization of Black Immigration', Immigrants and Minorities, 6/3 (1987): 335-47.

Carter, B. C. H., and S. Joshi, 'Immigration Policy and the Racialization of Migrant Labour: The Construction of National Identities in the USA and Britain', Ethnic and Racial Studies, 19/1 (1996), 135-57.

Centre for Contemporary Cultural Studies, Empire Strikes Back: Race and Racism in 70s Britain (London: Hutchinson, 1982).

Chamberlain, M., Narratives of Exile and Return (London: MacMillan, 1997).

Chamberlain, M., Family Love in the Diaspora: Migration and the Anglo-Caribbean Experience (Piscataway, NJ: Transaction Publishers, 2009).

Cleaver, K., 'Back to Africa: The Evolution of the International Section of the Black Panther Party, 1969-1972', in C. E. Jones, (ed.), The Black Panther Party (Reconsidered) (Baltimore: Black Class Press, 1998): 211-54.

Deakin, N., 'The Politics of the Commonwealth Immigrants Bill', Political Quarterly, 39 (1968), 25-45.

Duke, E. D., Building a Nation: Caribbean Federation in the Black Diaspora (Gainesville: University of Florida Press, Forthcoming, 2015).

Edwards, B. H., The Practice of Diaspora: Literature, Translation and the Rise of Black Internationalism (Cambridge: Harvard University Press, 2004).

Esedebe, P. O., Pan-Africanism: The Idea and Movement, 1776-1991 (Washington, D.C.: Howard University Press, 1994).

Foot, P., Immigration and Race in British Politics (Harmondsworth: Penguin, 1965).

Frost, D., Work and Community Among West African Migrant Workers Since the Nineteenth Century (Liverpool: Liverpool University Press, 1999)s.

Fryer, P., Staying Power: The History of Black People in Britain (London: Pluto Press, 1984). 
Geiss, I., The Pan-African Movement: A History of Pan-Africanism in America, Europe and Africa, trans. A. Keep (New York: Holmes and Meier, 1974).

Gilmore, G., Defying Dixie: The Radical Roots of Civil Rights, 1919-1950 (New York: W.W. Norton, 2009).

Gilroy, P., Ain't No Black in the Union Jack: The Cultural Politics of Race and Nation (Chicago: University of Chicago Press, 1987). Gilroy, P., The Black Atlantic: Modernity and Double Consciousness (Cambridge: Harvard University Press, 1993).

Gilroy, P., Black Britain: A Photographic History (London: Saqi Book, 2007).

Guild, J., "You Can't Go Home Again: Migration, Citizenship, and Black Community in Postwar New York and London," PhD Dissertation, Yale University, 2007.

Guild, J., Shadows of the Metropolis: Cultural Politics and Black Communities in Postwar Brooklyn and London (New York: Oxford University Press, forthcoming, 2015).

Hall, S., 'Racism and Reaction', in Five Views of Multi-racial Britain (London: Commission for Racial Equality, 1978)

Hall, S., "A Question of Identity," The Observer 15 October 2000.

Hall, C., Civilising Subjects: Metropole and Colony in the English Imagination, 1830-1867. (Chicago: University of Chicago Press, 2002).

Hampshire, J., Citizenship and Belonging: Immigration and the Politics of Demographic Governance in Postwar Britain (London: Palgrave Macmillan, 2005).

Hansen, R., Citizenship and Immigration in Postwar Britain: The Institutional Origins of a Multiracial Nation (Oxford: Oxford University Press, 2000).

Hesse, B., 'Diasporicity: Black Britain's Post-colonial Formations', in Barnor H., (ed.), Un/Settled Multiculturalisms (London: Zed Books, 2000): 96-120.

Hiro, D., Black British, White British: A History of Race Relations in Britain (London: Paladin, 1992).

Høgsbjerg, C., C. L. R. James in Imperial Britain (Durham: Duke University Press, 2014).

Holmes, C., John Bull's Island: Immigration and British Society, 1871-1971 (Houndsmill: Macmillan Press, 1988).

Horne, G., Mau Mau in Harlem: The U.S. and the Liberation of Kenya (New York: Palgrave, 2012).

James, W., 'Migration, Racism and Identity Formation', in W. James and C. Harris (eds.), Inside Babylon: The Caribbean Diaspora in Britain (London: Verso, 1993): 231-87.

Jarret-Macauley, D., The Life of Una Marson, 1905-1965 (Manchester: Manchester University Press, 1988).

Jeffries, H. K., Bloody Lowndes: Civil Rights and Black Power in Alabama's Black Belt (New York: NYU Press, 2010).

Jenkins, J., Black Riot: Riots, Racism and Resistance in Imperial Britain (Liverpool: Liverpool University Press, 2009).

Joseph, P., Waiting Til' The Midnight Hour: A Narrative History of Black Power in America (New York: Henry Holt, $2006 \mathrm{a})$.

Joseph, P., ed., The Black Power Movement: Rethinking the Civil Rights-Black Power Era (New York: Routledge, 2006b).

Joseph, P., 'The Black Power Movement: A State of the Field', Journal of American History, 96/3 (December, 2009): 1-26.

Kelley, R., and Patterson, T., 'Unfinished Migrations: Reflections on the African Diaspora and the Making of the Modern World', African Studies Review, 43/1 (April, 2000): 11-45.

Killingray, D. (ed.), Africans in Britain (London: Frank Cass, 1994).

Killingray, D., "A Good West Indian, a Good African and in Short a Good Britisher': Black and British in a ColourConscious Empire', Journal of Imperial and Commonwealth History, 36 (September, 2008): 363-81.

Layton-Henry, Z., The Politics of Immigration: Immigration, 'Race' and 'Race Relations' in Post-War Britain (Oxford: Blackwell Publishers, 1992).

Lindsey, L., "The Role of Immigration Policy, Race, Class, and Gender in Shaping the Status of Jamaican Immigrant Women Workers in Birmingham, England, 1948-1962," PhD Dissertation, University of North Carolina at Chapel Hill, 1992.

Little, K., Negroes in Britain: A Study of Racial Relations in British Society (London: Kegan Paul, 1948).

Makalani, M., In the Cause of Freedom: Radical Black Internationalism from Harlem to London, 1917-1939 (Chapel Hill: University of North Carolina at Chapel Hill, 2011).

Martin, T., Amy Ashwood Garvey: Pan-Africanist, Feminist and Mrs. Marcus Garvey No. 1 or a Tale of Two Amies (Dover, MA: Majority Press, 2007).

Matera, M., 'Colonial Subjects: Black Intellectuals and the Development of Colonial Studies in Britain', Journal of British Studies, 49 (April, 2010): 388-418.

Matera, M., Black London: The Imperial Metropolis and Decolonization in the Twentieth Century (Berkeley: University of California Press, forthcoming, 2015).

McClintock, A., Imperial Leather: Race, Gender and Sexuality in the Colonial Conquest (London: Routledge, 1995).

Mead, M., 'Empire Windrush: The Cultural Memory of an Imaginary Arrival', Journal of Postcolonial Writing, 45/2 (2009): 137-49.

Meriwether, J. H., Proudly We Can Be Africans: Black Americans and Africa, 1935-1961 (Chapel Hill: University of North Carolina Press, 2001).

Miles, R., 'Nationality, Citizenship and Migration to Britain, 1945-1951', Journal of Law and Society, 16/4 (Winter, 1989), 426-42.

Modood, T. 'Political Blackness and British Asians', Sociology, 28 (November, 1994): 859-876. 
Murch, D., Living For The City: Migration, Education, and the Rise of the Black Panther Party in Oakland, California (Chapel Hill: UNC Press, 2010).

Nelson, A., Body and Soul: The Black Panther Party and the Fight Against Medical Discrimination (Minneapolis: University of Minnesota Press, 2011).

Panayi, P., (ed.), Racial Violence in Britain, 1840-1950 (Leicester: Leicester University Press, 1996).

Paul, K., Whitewashing Britain: Race and Citizenship in the Postwar Era (Ithaca: Cornell University Press, 1997).

Pennybacker, S., From Scottsboro to Munich: Race and Political Culture in 1930s Britain (Princeton: Princeton University Press, 2009). Perry, K. H., 'Little Rock' in Britain: Jim Crow's Transatlantic Topographies', Journal of British Studies, 51/1 (2012): $155-177$.

Perry, K. H., 'U.S. Negroes, Your Fight Is Our Fight: Black Britons and the 1963 March on Washington', in S. Tuck and R.

D. G. Kelley, (eds.), The Other Special Relationship: Race and Rights in Britain and America (London: Palgrave, forthcoming, 2014).

Phillips, T., and Phillips, M., Windrush: The Irresistible Rise of Multi-racial Britain (London: Harper Collins, 1998).

Plummer, B. G., Rising Wind: Black Americans and U.S. Foreign Affairs, 1935-1960 (Chapel Hill: University of North Carolina Press, 1996).

Plummer, B. G., In Search of Power: African Americans in the Era of Decolonization, 1956-1974 (Cambridge: Cambridge University Press, 2012).

Proctor, J. (ed.), Writing Black Britain, 1948-1998: An Interdisciplinary Anthology (Manchester: Manchester University Press, 2000).

Putnam, L., 'Citizenship From the Margins: Vernacular Theories of Rights and the State in the Interwar Caribbean', Journal of British Studies, 53 (2014): 162-91.

Ramdin, R., The Making of the Black Working Class in Britain (London: Gower, 1987).

Rich, P., Race and Empire in British Politics (Cambridge: Cambridge University Press, 1990).

Robinson, C., Black Marxism: The Making of the Black Radical Tradition (Chapel Hill: UNC Press, 2005).

Rose, S., 'Who Are We Now?: Writing the Postwar 'Nation', 1948-2001', in K. McClelland and C. Hall (eds.), Race, Nation and Empire: Making Histories, 1750 to the Present (Manchester: Manchester University Press, 2010).

Rush, A., 'Imperial Identity in Colonial Minds: Harold Moody and the League of Coloured Peoples', Twentieth Century British History, 13 (2002): 356-83.

Schwarz, B., 'Claudia Jones and the West Indian Gazette: Reflections on the Emergence of Post Colonial Britain', Twentieth Century British History 14, 3 (2001): 264-85.

Schwarz, B. (ed.), West Indian Intellectuals in Britain (Manchester: Manchester University Press, 2004).

Schwarz, B., The White Man's World (Oxford: Oxford University Press 2011).

Sherwood, M., Origins of Pan-Africanism: Henry Sylvester Williams, Africa and the African Diaspora (London: Routledge, 2012).

Sivanandan, A., 'Race and Resistance: The IRR Story'. Race and Class, 50 (2008): 1-30.

Slate, N. (ed.), Black Power Beyond Borders: The Global Dimensions of the Black Power Movement (New York: Palgrave Macmillan, 2012).

Spencer, I., British Immigration Policy Since 1939:

Spencer, N., 'Lord Kitchener Steps Off the Empire Windrush', The Guardian, 15 (June 2011): 7.

Street, J., 'Malcolm X, Smethwick, and the Influence of the African American Freedom Struggle', Journal of Black Studies 38, 6 (2008): 932-950.

Swan, Q., Black Power in Bermuda: The Struggle for Decolonization (New York: Palgrave Macmillan, 2009).

Tabili, L., We Ask for British Justice: Workers and Racial Difference in Late Imperial Britain (Ithaca: Cornell University Press, 1997).

Tabili, L., Global Migrants, Local Culture: Natives and Newcomers in Provincial England, 1841-1939 (Basingstoke: Palgrave Macmillan, 2011).

Thorne, S., Congregational Missions and the Making of an Imperial Culture in Nineteenth Century England (Stanford: Stanford University Press, 1999).

Tuck, S., 'Malcolm X's Visit to Oxford University: U.S. Civil Rights, Black Britain, and the Special Relationship on Race', American Historical Review, 118 (2013): 76-103.

Visram, R., Asians in Britain: 400 Years of History (London: Pluto Press, 2002).

Von Eschen, P., Race Against Empire: Black Americans and Anti-colonialism (Ithaca: Cornell University Press, 1997).

Walters, R., Pan-Africanism in the African Diaspora: An Analysis of Modern Afrocentric Political Movements (Detroit: Wayne State University Press, 1997).

Walvin, J., Passage to Britain: Immigration in British History and Politics (London: Penguin, 1984).

Wambu, O., Empire Windrush: Fifty Years of Writing About Black Britain (London: Victo Gollancz, 1998).

Ward, B., 'A King in Newcastle: Martin Luther King, Jr. and British Race Relations, 1967-1968', Georgia Historical Quarterly, 79, 3 (1995): 599-632.

Waters, C. 'Dark Strangers' in Our Midst: Discourses of Race and Nation in Britain, 1947-1963', Journal of British Studies, 36, 2 (1997): 207-38.

Webster, W., Imagining Home: Gender, Race and National Identity, 1945-1965 (London: Routledge, 1998).

Wild, R. "Black Was the Colour of Our Fight: Black Power in Britain, 1955-1976," PhD Dissertation, University of Sheffield, 2008. 